\title{
USE OF SERIOUS GAMES FOR COPING WITH CHILDHOOD OBESITY: INTEGRATIVE LITERATURE REVIEW
}

\author{
Jéssica David Dias ${ }^{1}$, Chris Mayara dos Santos Tibes², Luciana Mara Monti Fonseca², \\ Silvia Helena Zem-Mascarenhas ${ }^{4}$
}

${ }^{1}$ Doctoral student, Escola de Enfermagem de Ribeirão Preto (EERP) Universidade de São Paulo (USP). Ribeirão Preto, São Paulo, Brazil. E-mail: jessddias23@gmail.com

${ }^{2}$ Doctoral student, EERP/USP. Ribeirão Preto, São Paulo, Brazil. E-mail: christibes@gmail.com

${ }^{3}$ Ph.D. in Nursing Public Health. Professor, Maternal-Infant and Public Health Nursing Department, EERP/USP. Ribeirão Preto, São Paulo, Brazil. E-mail: lumonti@eerp.usp.br

${ }^{4}$ Ph.D. in Primary Care Nursing Professor. Nursing Department, Universidade Federal de São Carlos. São Carlos, São Paulo, Brasil. E-mail: cilviazem@gmail.com

\begin{abstract}
Objective: was to identify studies in the scientific literature in which the serious game is used as a strategy to prevent and/or treat childhood obesity.

Method: an integrative review. The search in the databases resulted in 466 studies, 17 of which were elected for analysis.

Results: the use of serious games for health promotion could positively influence children's health and promote behavior changes, as well as encourage healthier habits.

Conclusion: the use of serious games can be a powerful strategy for child health education. Considering the use of technology by children, we believe in the potential of these resources to change this population's behavior, particularly with regard to childhood obesity. DESCRIPTORS: Pediatric nursing. Obesity. Medical informatics. Video games.
\end{abstract}

\section{USO DE SERIOUS GAMES PARA ENFRENTAMENTO DA OBESIDADE INFANTIL: REVISÃO INTEGRATIVA DA LITERATURA}

\section{RESUMO}

Objetivo: identificar na literatura científica estudos que utilizam como estratégia o serious game na prevenção e/ou tratamento da obesidade infantil.

Método: revisão integrativa. A busca nas bases de dados resultou em 466 estudos e elegeu-se 17 trabalhos para análise.

Resultados: a utilização de serious games para a promoção da saúde pode refletir positivamente na saúde das crianças, bem como promover a mudança de comportamentos e estimular hábitos saudáveis.

Conclusão: o uso de serious games pode ser uma estratégia potente para a educação em saúde de crianças. Considerando a utilização de tecnologias pelo público infantil, acredita-se no potencial desses recursos para a mudança de comportamentos dessa população.

DESCRITORES: Enfermagem pediátrica. Obesidade. Informática médica. Jogos de vídeo. 


\title{
USO DE SERIOUS GAMES PARA EL ENFRENTAMIENTO DE LA OBESIDAD INFANTIL: REVISIÓN INTEGRADORA DE LA LITERATURA
}

\author{
RESUMEN \\ Objetivo: identificar estudios científicos en la literatura científica que utilizan el serious game como estrategia en la prevención y/o \\ tratamiento de la obesidad infantil. \\ Método: una revisión integradora. La búsqueda en las bases de datos resultó en 466 estudios y se eligieron 17 trabajos para análisis. \\ Resultados: la utilización de serious games para la promoción de la salud puede impactar positivamente en la salud de los niños y niñas, \\ así como promover el cambio de comportamientos y estimular hábitos saludables. \\ Conclusión: el uso de serious games puede ser una estrategia potente para la educación en salud de niños y niñas. Considerando la \\ utilización de tecnologías por el público infantil, se cree en el potencial de esos recursos para cambiar comportamientos de esa población. \\ DESCRIPTORES: Enfermería pediátrica. Obesidad. Informática médica. Juegos de video.
}

\section{INTRODUCTION}

The global and Brazilian panoramas of obesity have brought a new challenge for public health, as its incidence and prevalence rates have grown at an alarming pace in the last 30 years. ${ }^{1-2}$

To fight obesity, health policies in Brazil and around the world have established a set of interdisciplinary and multisectoral targets with a view to health promotion. ${ }^{3-4}$ New strategies are needed to offer health education to children, which is the case of games. ${ }^{5}$

The new generations of children are already born and live in a world surrounded with digital technologies and are accustomed since childhood to a hypermedia and interactive language, which makes it difficult for these children to adapt to a traditional teaching strategy. ${ }^{6}$ Therefore, prevention and health promotion programs need to update through technological resources.

In that context, educational games and gamebased learning increasingly stand out, as they are more aligned with these new learning styles and with the needs of the new generations. The educational approach based on electronic games can be useful and well received. In addition, it integrates playful characteristics and specific contents, thus motivating the children's learning process. ${ }^{7}$

Hence, it is important to include serious games in the health area. A serious game is a game in which education is the main objective. That does not mean, however, that this kind of games is not funny, but simply that they reinforce another goal than fun. ${ }^{8}$ These games permit the presentation of new situations, the discussion of better ways to solve them, besides permitting the construction of knowledge and training for particular activities, offering opportunities for learning and behavioral changes. ${ }^{7}$

The combination of stimulus and different artistic elements favors the learning process and motivates the child to comply with the treatment. In addition, children with obesity need to perceive the needs for changes in their life habits and for dietary education based on a playful context, thus aiming for health promotion. ${ }^{6}$

Considering the use of technologies by children and adolescents, these resources can change behaviors in this population, particularly regarding eating habits, helping to cope with childhood obesity. The objective in this study was to identify articles in the scientific literature which used the serious game as a strategy to prevent and/or treat childhood obesity.

\section{METHOD}

To develop the integrative review, the model was used consists of the following steps: ${ }^{9}$ establishing of research hypothesis or question; sampling or literature search; categorization of the studies; assessment of studies included in the review; interpretation of the results; and synthesis of the knowledge or presentation of the review.

To guide the integrative review, the following research question was formulated: what studies presented in the scientific literature use the serious game as a strategy to prevent and/or treat childhood obesity? To select the articles, the following databases were used: Lilacs, Medline and Web of Science. These databases were chosen because LILACS covers the literature published in Latin American and Caribbean countries, while Medline and Web of Science cover the international literature, including highly rated journals in health, and offer an enhanced perspective of the scientific literature on the theme. The studies found in more than one database were considered only once.

The following inclusion criteria were considered: articles reporting on original studies, published in Portuguese, English or Spanish between 2009 and 2014. The exclusion criteria were: monographs, dissertations, theses, literature review, repeated texts in the databases and articles that did not address the theme. The key words used for the search were 
video games, serious games and obesity, combined in pairs using the Boolean search term and.

The studies were selected in phases. First, studies were excluded based on the reading of titles (first analysis), then abstracts (second analysis), and finally the reading of the full texts (third analysis). Table 1 presents an overall picture of the selection process according to the scientific bases.

Table 1 - General picture of studies selected according to the scientific bases

\begin{tabular}{lcccc}
\hline \multirow{2}{*}{ Selection of studies } & \multicolumn{2}{c}{ Studies found in each database } & \multirow{2}{*}{ Total } \\
\cline { 2 - 4 } & LILACS & Medline & $\begin{array}{c}\text { Web of } \\
\text { Science }\end{array}$ & \\
\hline Studies selected in the initial search & 9 & 182 & 275 & 466 \\
After reading the titles & 1 & 30 & 28 & 59 \\
After reading the abstracts & - & 6 & 13 & 19 \\
After reading the full text & - & 6 & 11 & 17 \\
\hline
\end{tabular}

Figure 1 illustrates the selection process of the articles.

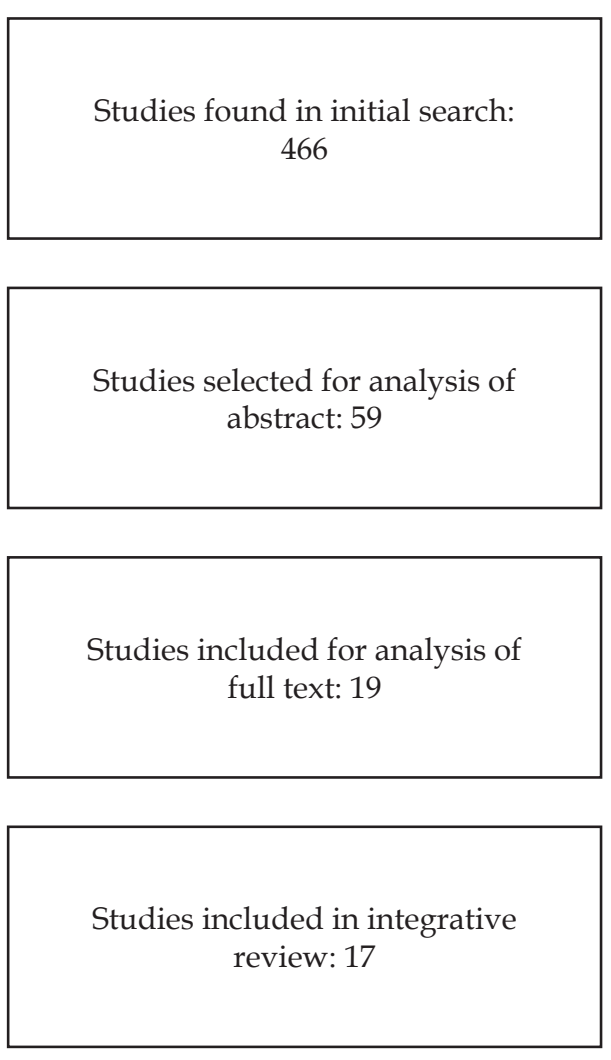

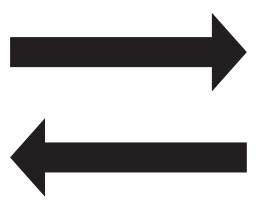
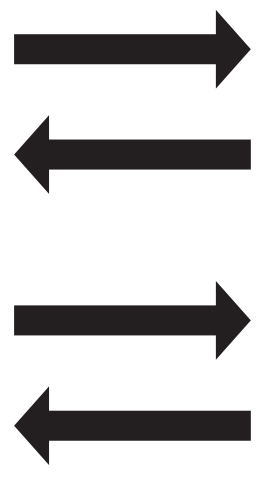

Studies excluded (first analysis): 407

Reason: Articles in which the relation with the theme could not be identified by reading the titles.

Studies excluded (second analysis): 40

Reason: Literature reviews, articles repeated in more than one database and beyond the research theme, based on the reading of the abstracts.

Studies excluded (third analysis): 02

Reason: Articles beyond the research theme after reading the full text.

\section{Figure 1 - Synthesis of article selection process for the integrative review}

An adaptation of the instrument to extract and analyze data from studies in an integrative review ${ }^{10}$ was used, especially constructed for this purpose with the following items: title, authors, method used, database the study was found in, year of publication, place of origin of the research, evidence level, study objective and main results.
To classify the evidence level of the studies was considered the quality of evidence in six levels, ${ }^{11}$ ranging from the best evidence possible, studies deriving from meta-analyses and randomized clinical trials, to the opinions of experts and respectable authorities, considered to be the bottom level of scientific evidence. 
Then, the data collected through the analysis tool were organized in a Microsoft Excel worksheet. After reading the full versions of the selected studies, the analysis was undertaken to describe and rank the results, evidencing the knowledge produced about the theme, followed by the thematic categorization.

\section{RESULTS}

The search in the databases resulted in 466 studies. After applying the inclusion and exclusion criteria, 17 articles were maintained for detailed analysis. To better identify each selected study, the articles were organized in alphanumerical order from A1 till A17 (Table 2).

\section{Table 2 - Studies selected for analysis}

\begin{tabular}{|c|c|c|}
\hline No. & & Article data \\
\hline$A 1^{12}$ & $\begin{array}{l}\text { Title } \\
\text { Authors } \\
\text { Year }\end{array}$ & $\begin{array}{l}\text { Effects of an exercise intervention using Dance Dance Revolution on endothelial function and } \\
\text { other risk factors in overweight children. } \\
\text { Murphy ECS, et al. } \\
2009\end{array}$ \\
\hline $\mathrm{A} 2^{13}$ & $\begin{array}{l}\text { Title } \\
\text { Authors } \\
\text { Year }\end{array}$ & $\begin{array}{l}\text { Tipping the balance: use of advergames to promote consumption of nutritious foods and bever- } \\
\text { ages by low-income african american children. } \\
\text { Pempek TA, Calvert SL. } \\
2009\end{array}$ \\
\hline $\mathrm{A} 3^{14}$ & $\begin{array}{l}\text { Title } \\
\text { Authors } \\
\text { Year }\end{array}$ & $\begin{array}{l}\text { The effects of exergaming on physical activity among inactive children in a physical education } \\
\text { classroom. } \\
\text { Fogel VA, et al. } \\
2010\end{array}$ \\
\hline$A 4^{15}$ & $\begin{array}{l}\text { Title } \\
\text { Authors } \\
\text { Year }\end{array}$ & $\begin{array}{l}\text { The effect of active video gaming on children's physical activity, behavior preferences and body } \\
\text { composition. } \\
\text { Graves LEF, et al. } \\
2010\end{array}$ \\
\hline $\mathrm{A} 5^{16}$ & $\begin{array}{l}\text { Title } \\
\text { Authors } \\
\text { Year }\end{array}$ & $\begin{array}{l}\text { Feasibility of activity-promoting video games among obese adolescents and young adults in a } \\
\text { clinical setting. } \\
\text { Radon K, et al. } \\
2011\end{array}$ \\
\hline $\mathrm{A} 6^{17}$ & $\begin{array}{l}\text { Title } \\
\text { Authors } \\
\text { Year }\end{array}$ & $\begin{array}{l}\text { Video game play, child diet, and physical activity behavior change: a randomized clinical trial. } \\
\text { Baranowski T, et al. } \\
2011\end{array}$ \\
\hline$A 7^{18}$ & $\begin{array}{l}\text { Title } \\
\text { Authors } \\
\text { Year }\end{array}$ & $\begin{array}{l}\text { The quest to lava mountain: using video games for dietary change in children. } \\
\text { Beasley N, et al. } \\
2012\end{array}$ \\
\hline$A 8^{19}$ & $\begin{array}{l}\text { Title } \\
\text { Authors } \\
\text { Year }\end{array}$ & $\begin{array}{l}\text { Exergaming for health: a community-based pediatric weight management program using active } \\
\text { video gaming. } \\
\text { Christison A, Khan HA. } \\
2012\end{array}$ \\
\hline $\mathrm{A} 9^{20}$ & $\begin{array}{l}\text { Title } \\
\text { Authors } \\
\text { Year }\end{array}$ & $\begin{array}{l}\text { Interval training with astrojumper. } \\
\text { Nickel A, et al. } \\
2012\end{array}$ \\
\hline $\mathrm{A}_{10}{ }^{21}$ & $\begin{array}{l}\text { Title } \\
\text { Authors } \\
\text { Year }\end{array}$ & $\begin{array}{l}\text { Memapads: enhancing children's well-being through a physically interactive memory and math } \\
\text { games. } \\
\text { Karime A, et al. } \\
2012\end{array}$ \\
\hline $\mathbf{A}_{11}^{22}$ & $\begin{array}{l}\text { Title } \\
\text { Authors } \\
\text { Year }\end{array}$ & $\begin{array}{l}\text { Video game-based exercise, latino children's physical health, and academic achievement. } \\
\text { Gao Z, et al. } \\
2013\end{array}$ \\
\hline
\end{tabular}




\begin{tabular}{|c|c|c|}
\hline $\mathrm{A}^{123}$ & $\begin{array}{l}\text { Title } \\
\text { Authors } \\
\text { Year }\end{array}$ & $\begin{array}{l}\text { A cloud-based pervasive serious game framework to support obesity treatment. } \\
\text { Alamri A, Hossain MA, Hassan MM, et al. } \\
2013\end{array}$ \\
\hline $\mathrm{A}_{13}{ }^{24}$ & $\begin{array}{l}\text { Title } \\
\text { Authors } \\
\text { Year }\end{array}$ & $\begin{array}{l}\text { Introduction of active video gaming into the middle school curriculum as a school-based child- } \\
\text { hood obesity intervention. } \\
\text { Quinn M. } \\
2013\end{array}$ \\
\hline $\mathrm{A}^{14} 4^{25}$ & $\begin{array}{l}\text { Title } \\
\text { Authors } \\
\text { Year }\end{array}$ & $\begin{array}{l}\text { Improved metabolic and cardiorespiratory fitness during a recreational training program in } \\
\text { obese children. } \\
\text { Calcaterra V, et al. } \\
2013\end{array}$ \\
\hline $\mathrm{A}^{2} 5^{26}$ & $\begin{array}{l}\text { Title } \\
\text { Authors } \\
\text { Year }\end{array}$ & $\begin{array}{l}\text { Efficacy and acceptability of an Internet platform to improve the learning of nutritional knowl- } \\
\text { edge in children: the ETIOBE mates } \\
\text { Baños RM, et al. } \\
2013\end{array}$ \\
\hline A16 ${ }^{27}$ & $\begin{array}{l}\text { Title } \\
\text { Authors } \\
\text { Year }\end{array}$ & $\begin{array}{l}\text { Effects of a pediatric weight management program with and without active video games: a } \\
\text { randomized trial } \\
\text { Trost SG, et al. } \\
2014\end{array}$ \\
\hline $\mathbf{A}^{128}$ & $\begin{array}{l}\text { Title } \\
\text { Authors } \\
\text { Year }\end{array}$ & $\begin{array}{l}\text { PEGASO: a personalised and motivational ICT system to empower adolescents towards healthy } \\
\text { lifestyles. } \\
\text { Carrino S, et al. } \\
2014\end{array}$ \\
\hline
\end{tabular}

The selected studies were summarized and classified according to the year of publication, evidence level and thematic approach. Concerning the year of publication, 2013 stood out with five selected studies. Next comes 2012 with four studies and, finally, 2009, 2010, 2011 and 2014 with two studies each.

Six studies were classified under evidence level four, being non-experimental, descriptive and applied studies or having qualitative designs. Five studies were considered as evidence level three, as they described quasi-experimental research. Finally, six studies were classified under evidence level two because they reported on actual experimental research.

In the course of the reading, a dichotomy was perceived between the articles that presented the use of active (exergames) and inactive games (serious games). Despite the separation between the categories, the active game, also known as ex- ergame, is considered a subcategory of the serious game. Nevertheless, among the selected studies, a different focus was noticed when the study involved the exergame. Exergames are interactive games that demand physical activity from the player. They can enhance children's physical activity by combining fun and exercise. ${ }^{29}$

Authors who developed studies involving active games used platforms and movement technologies. On the other hand, researchers who chose to use inactive games focused on the persuasive aspect of the serious game to change behaviors. The categories were designated after reading the full version of all articles. Thus, the studies were separated in two categories: "the use of serious games for coping with childhood obesity" and "the use of exergames to cope with childhood obesity". The studies indicated for each category have been described in Table 3.

Table 3 - Classification of studies in thematic categories

\begin{tabular}{|l|r|}
\hline \multicolumn{1}{|c|}{ Categories } & Selected articles \\
\hline The use of serious games to cope with childhood obesity & A2, A6, A7, A15, A17 \\
\hline The use of exergames to cope with childhood obesity & A1, A3, A4, A5, A8, A9, A10, A11, A12, \\
& \begin{tabular}{c} 
A13, A14, A16 \\
\hline
\end{tabular} \\
\hline
\end{tabular}




\section{The use of serious games to cope with childhood obesity}

In this category, five studies were selected on the use of serious games as a strategy to prevent and treat childhood obesity. All studies reported on the use of persuasion and motivation to achieve behavioral changes and improve children's eating habits. Four studies were intended to develop serious games for the childhood public, focusing on healthy eating and physical exercise. ${ }^{12,17,25,27}$

Pempek and Calvert ${ }^{12}$ developed their game based on the Pac-Man gaming style. The authors created two versions of the game, one containing healthy foods (fruit and vegetables), and the other unhealthy foods (fried foods and soft drinks). In the first version, the child receives one point each time it collects the healthy good. In the second version, the player gains points when he collects the unhealthy foods. Thus, the children were divided in three groups: one group only played the healthy version of the game, another only the unhealthy version and the final group served as the control group. They noted an increase in the intervention group children's preference for healthy snacks to the detriment of industrialized and less healthy ones, thus strengthening the idea of promoting healthy foods in games to persuade the children in their food choices, making them healthier.

Beasley et $\mathrm{al}^{17}$ discuss the game The quest to Lava Mountain, a 3D web-based serious game involving immersion, action and adventure. The game focuses on nutrition, using knowledge on the theme to help the participants to understand how they can enhance their health. The players choose a character and can complete missions to move forward in the game. The game is under development and no tests with the target public have been undertaken thus far.

Banõs et $\mathrm{al}^{25}$ proposed an on-line serious game to provide nutritional information to children. The objective of the study was to verify the efficacy and acceptability of the game, called "ETIOBE Mates", which was created to improve children's nutritional knowledge. In addition, the authors also compared the knowledge improvement through the serious game with a traditional pen-and-paper model of nutritional information transmission. A sample of 228 children participated in the study. The participants were divided in two groups: one experimental group (which used ETIOBE Mates) and one control group (which received an information leaflet). Both groups enhanced their knowledge about nutrition, but the study indicated that the acquisition of nutri- tional knowledge was superior in the experimental group. The children considered the game useful to improve their nutritional knowledge.

Carrino et $\mathrm{al}^{27}$ explain an ongoing project called "PEGASO", intended to develop a multidimensional and interdisciplinary ICT (information and communication technology) system to promote healthy behaviors among children and adolescents, enhance the user's motivation to maintain a healthier lifestyle and, finally, facilitate behavioral changes. The adoption of the smartphone as the main interface will permit the development of games that can link healthy habits with the promotion of physical exercise in the dynamics of a game. In addition, PEGASO will not be limited to the game or applications. It will also suggest activities, educational material, promoting health education and providing ideas on the information gained.

Only one study used serious games previously developed by other institutions, ${ }^{16}$ Escape from diab and Nanoswarm: invasion from inner Space. Escape from diab is a 3D web-based adventure game about healthy eating and physical exercise. Nanoswarm: invasion from inner space is a 2D serious game with adventure and science-fiction in which the player is expected to solve puzzles along the way. Baranowski et $\mathrm{al}^{16}$ used Escape from diab and Nanoswarm: invasion from inner space in a randomized clinical trial with the child public. After the intervention, improvement was observed in the preference for healthier foods, improvement in the anthropometric measures and increased physical exercise when compared to the control group, but only the dietary preference was statistically significant.

\section{The use of exergames to cope with childhood obesity}

Eleven studies were selected for this category. Most studies used previously developed exergames and applied them to the target public in order to verify their efficacy in an educational program. $11,13,15,18,21,23-24,26$

Some researchers used well-known commercial dance games like Dance dance revolution or Just dance, ${ }^{11,13,18,21,23}$ while other authors used commercial sports games like PlaySports, Wii sports or Kinect sports ${ }^{15,24,26}$ as part of educational health promotion programs.

The authors perceived positive impacts when using active games, as well as better adherence to physical exercise through the games' attractive interface and improvement in the participants' 
physiological data. In addition, the results also suggest that exergames can be included in physical education classes in schools and are well-accepted among teachers and students. ${ }^{13,24}$

Other studies developed an exergame for use with children and adolescents. ${ }^{14,20,22}$ According to the results of these studies, the games were well-accepted by the target public and the children found them stimulating, demonstrating that they learned through the games. Only one study explained about the development of an exergame and announced tests in future research, as the game is still under development. ${ }^{19}$

Alamri et $\mathrm{al}^{22}$ developed a $3 \mathrm{D}$ pervasive exergame called Treasure hunting. They used cloud computing to execute the game, allowing many players from different places to take part. The game interactions are received based on the player's movement. When the game starts, the screen displays the mission and strategies suggested based on the BMI measure, age, sex and caregiver/therapist mission. The objective is to achieve a better lifestyle, encourage healthy eating and more directly stimulate physical exercise. It was also verified that exergames can be included in schools and that their use encourages weight loss, thus preventing childhood obesity. ${ }^{22}$

One study involved not only the encouragement of physical exercise, but also mental stimulus, through games that involved the use of mathematics or memory combined with physical exercise. ${ }^{20}$ The authors presented an exergame called MeMaPads, which consists of a sensory carpet used to interact with two games: one memory game and one mathematics game. The assessments involving the target public demonstrated that MeMaPads can be useful to fight against obesity and improve children's cognitive development. ${ }^{20}$

Graves et $\mathrm{al}^{14}$ developed an alternative approach to physical exercise in games the children already have, but which are inactive. A peripheral device permits physical activity while playing, called jOG (New Concept Gaming Ltd, LiverpoolUK). jOG is compatible with PlayStation II and III and Nintendo Wii consoles. Nevertheless, the use of jOG at home and its impact on the children's physical activity was unknown. Therefore, the authors developed a randomized clinical trial to assess the effects of using the device. Participants in the intervention received two jOG devices for use at home, aiming to discourage the use of the sedentary game. jOG connects a pedometer to the standard console and encourages the players to step on site to use guiding controls and produce the character's movement on the screen in games. At the end of the study, an increase was observed in the preference for active playing and a reduction in inactive games, although without a statistically significant reduction in the participants' fat percentage.

Finally, Nickel et $\mathrm{al}^{19}$ discuss an exergame under development called Astrojumper. The game was conceived to involve autistic children in physical exercise and explore effective fun and mechanics, aiming to achieve effective exercises, increased cardiac frequency and a pleasant experience. The game takes place in a spatial environment and the players are expected to evade from the planets that are flying towards them. The preliminary results of a study involving some users demonstrated that the game was considered effective to enhance the users' cardiac capacity.

\section{DISCUSSION}

The findings of the integrative review revealed a wide range of serious games applied to health. Greater investments and research in active games are observed, called exergames. The data revealed that the publications in the research line serious games applied to childhood obesity are an expanding field. Publications on the theme are expanding, enhancing its popularization.

The analysis of the studies showed that two distinct categories of games focused on the child audience exist, which help to fight against obesity, games that reinforce behavioral changes and adherence to healthy habits and games that directly encourage physical exercise, which are the motivational factors in active games. The review ranged from games that promote physical improvement and healthier life habits to games that go beyond the objective of improving the life habits, also entailing an improvement in the child's cognitive functioning, which can be used for memory training, development of analytical and strategic skills, related to the findings in the scientific literature..$^{30-32}$

Vaghetti and Botelho ${ }^{30}$ analyzed the potential of exergames for use in health. In their results, the studies used existing games for Nintendo Wii and Play station 2, such as Dance dance revolution, while others presented the design of new exergames specifically developed for physical exercise. Conolly et al. ${ }^{31}$ developed a systematic literature review and investigated the positive impacts of educational games and serious games, as well as the engagement, learning and skills development of the players. The results revealed that playing these kinds of 
games is linked to a series of perceptual, cognitive, behavioral, affective and motivational impacts and benefits. In the results, the review highlighted the greater acquisition and understanding of contents addressed in the games, besides their affective and motivational benefits.

It can also be highlighted that the player's identification with the serious game through immersion favors entertainment and the development of teaching and learning processes. ${ }^{8}$ According to the study by Sparapani et al., ${ }^{32}$ the children demonstrated concern with finding ways to facilitate their understanding and learning about their disease. The authors found that the children preferred using games and playful activities when they were asked about what they would do to explain the disease to other children if they were the health professionals.

In addition, no integrative literature review with a similar theme has been identified in Brazil. Internationally, the review by Baranowski et al. ${ }^{33}$ discusses the use of video games for behavioral change related to health and physical exercise, but differs from this review as the author gave a broader view on the use of video games, while this review only discussed the use of serious games in the context of childhood obesity. Daley ${ }^{34}$ reviewed the scientific literature in search of randomized studies that used exergames in their interventions involving the child audience and observed few studies on the theme, so that their effectiveness and clinical relevance could not be assessed.

In addition, in the course of this integrative review, it was observed that the initial selection included few publications developed in Brazil. After the analyses, none of the Brazilian studies was included, evidencing a gap in the scientific literature.

\section{CONCLUSION}

Through an integrative review, the studies were verified that used serious games as a strategy to prevent and treat childhood obesity. There exists interest in the development and use of serious games to support coping with childhood obesity, which can adopt two different foci: persuade towards the player's behavioral changes, encourage direct physical activity based on physical exercise and stimulate improvements in healthy habits through an active game, the exergame.

Through the survey, a growing increase could be identified over the study period, particularly in 2013. Considering the potential and popularization of serious games and exergames for the health area, research in this context is still incipient and needs to be further explored.

In some of the studies analyzed, the authors developed the game and presented a prototype, which is not available yet for use in clinical practice. Other studies used well disseminated commercial games and were focused on its use in practice as a part of health promotion practices, with a view to checking for improvements in the physical conditions and the target audience's adherence.

As a limitation in this study, the non-inclusion of studies published in the form of congress papers, monographs, theses and dissertations can be highlighted, which were not added because they are available in specific databases not covered in this review.

Also, a gap is noticed with regard to publications in Brazil, in view of the rare Brazilian publications during the initial selection, none of which was maintained after the final selection. For the sake of future studies, the databases need to be expanded and theses and dissertations need to be included to cover publications that are still under development, and not just indexed articles.

The findings reveal that the use of games for health promotion is beneficial and well accepted by the child audience. The development of games for the purpose of health promotion needs further stimuli and investments.

\section{REFERENCES}

1. Reis CEG, Vasconcelos IAL, Barros JFN. Políticas públicas de nutrição para o controle da obesidade infantil. Rev Paul Pediatr. 2011; 29(4):625-33.

2. Wang Y, Monteiro C, Popkin BM. Trends of obesity and underweight in older children and adolescents in the United States, Brazil, China, and Russia. Am J Clin Nutr. 2002; 75(6):971-7.

3. Baptista MIM, Lima RM. Educação alimentar em meio escolar: referencial para uma oferta alimentar saudável. Lisboa (PT): Direção-geral de Inovação e de Desenvolvimento Curricular; 2006.

4. Ministério da Saúde (BR). Caderno do gestor do PSE/ Ministério da Saúde, Ministério da Educação. Brasília (DF): Ministério da Saúde; 2015.

5. Toscani NV, Santos AJDS, Silva LLM, Tonial CT, Chazan M, Wiebbelling AMP, et al. Desenvolvimento e análise de jogo educativo para crianças visando à prevenção de doenças parasitológicas. Interface Comunic, Saúde, Educ [Internet]. 2007 [cited 01 Jun 2015]; 11(22):281-94. Available from: http://www. scielo.br/pdf/icse/v11n22/08.pdf 
6. Savi R, Ulbricht VR. Hipermídia educacional, jogos digitais e simuladores. In: Anais da Conferência IADIS Ibero-Americana WWW/Internet Lisboa 2008. Lisboa (PT): Portugal; 2008.

7. Machado LS, Moraes RM, Nunes FLS, Costa RMEM. Serious games baseados em realidade virtual para educação médica. Rev Bras Educ Med. 2011; 35(2):254-62.

8. Abt CC. Serious games. Reprint. Originally published: New York: Viking Press, 1970. Lanham (US): University Press of America, 1987.

9. Mendes KDS, Silveira RCCP, Galvão CM. Revisão integrativa: método de pesquisa para a incorporação de evidências na saúde e na enfermagem. Texto Contexto Enferm. 2008; 17(4):758-64.

10. Ursi, ES. Prevenção de lesões de pele no perioperatório: revisão integrativa da literatura [dissertação]. Ribeirão Preto (SP): Universidade de São Paulo, Escola de Enfermagem de Ribeirão Preto; 2005.

11. Stetler CB, Morsi D, Rucki S, Broughton S, Corrigan $\mathrm{B}$, Fitzgerald J, et al. Utilization-focused integrative reviews in a nursing service. Appl Nurs Res. 1998; 11(4):195-206.

12. Murphy EC, Carson L, Neal W, Donley D, Yeater R. Effects of an exercise intervention using Dance Dance Revolution on endothelial function and other risk factors in overweight children. Int J Pediatr Obes. 2009; 4(4):205-14.

13. Pempek TA, Calvert SL. Tipping the balance: use of advergames to promote consumption of nutritious foods and beverages by low-income African American children. Arch Pediatr Adolesc Med. 2009; 163(7):633-7.

14. Fogel VA, Miltenberger RG, Graves R, Koehler S. The effects of exergaming on physical activity among inactive children in a physical education classroom. J Appl Behav Anal. 2010; 43(4):591-600.

15. Graves LEF, Ridgers ND, Atkinson G, Stratton G. The effect of active video gaming on children's physical activity, behavior preferences and body composition. Pediatr Exerc Sci. 2010; 22(4):535-46.

16. Radon K, Fürbeck B, Thomas S, Siegfried W, Nowak D, Kries R. Feasibility of activitypromoting video games among obese adolescents and young adults in a clinical setting. J Sci Med Sport. 2011; 14(1):42-5.

17. Baranowski T, Baranowski J, Thompson D, Buday R, Jago R, Griffith MJ, et al. Video game play, child diet, and physical activity behavior change a randomized clinical trial. Am J Prev Med. 2011; 40(1):33-8.

18. Beasley N, Sharma S, Shegog R, Huber R, Abernathy $P$, Smith C, et al. The quest to Lava Mountain: using video games for dietary change in children. J Acad Nutr Diet. 2012; 112(9):1334-6.

19. Christison A, Khan HA. Exergaming for health: a community-based pediatric weight management program using active video gaming. Clin Pediatr (Phila). 2012; 51(4):382-8.

20. Nickel A, Kinsey H, Haack H, Pendergrass M, Barnes T. Interval training with Astrojumper. In: Anais da IEEE Virtual Reality. Orange County, CA (US) 2012. p.161-2.

21. Karime A, Hafidh B, Khaldi A, El-Saddik A. MeMaPads: enhancing children's well-being through a physically interactive memory and math game. In: IEEE International Instrumentation and Measurement Technology Conference. Graz: Austria, 2012. p. 2563-6.

22. Gao Z, Hannan P, Xiang P, Stodden DF, Valdez VE. Video game-based exercise, Latino children's physical health, and academic achievement. Am J Prev Med. 2013; 44(3):240-6.

23. Alamri A, Hossain AM, Hassan MM, Hossain SM, Alnuem M, Ahmed TD, et al. A cloud-based pervasive serious game framework to support obesity treatment. Computer Science and Information Systems. 2013; 10(3):1229-46.

24. Quinn M. Introduction of active video gaming into the middle school curriculum as a school-based childhood obesity intervention. J Pediatr Health Care. 2013; 27(1):3-12.

25. Calcaterra V, Larizza D, Codrons E, Silvestri A, Brambilla P, et al. Improved metabolic and cardiorespiratory fitness during a recreational training program in obese children. J Pediatr Endocrinol Metab. 2013; 26(3-4):271-6.

26. Baños RM, Cebolla A, Oliver E, Alcañiz M, Botella C. Efficacy and acceptability of an Internet platform to improve the learning of nutritional knowledge in children: the ETIOBE Mates. Health Educ Res. 2013; 28(2):234-48.

27. Trost SG, Sundal D, Foster GD, Lent MR, Vojta D. Effects of a pediatric weight management program with and without active video games: a randomized trial. JAMA Pediatr. 2014; 168(5):407-13.

28. Carrino S, Caon M, Angelini L, Mugellini E, Abou Khaled O, Orte S, et al. PEGASO: a personalised and motivational ICT System to empower adolescents towards healthy lifestyles. Stud Health Technol Inform. 2014; 207:350-9.

29. Graf DL, Pratt LV, Hester CN, Short KR. Playing active video games increases energy expenditure in children. Pediatrics. 2009; 124(2):534-40.

30. Vaghetti CAO, Botelho SSC. Ambientes virtuais de aprendizagem na educação física: uma revisão sobre a utilização de Exergames. Ciências e Cognição. 2010; 15(1):76-88.

31. Connolly TM, Boyle EA, MacArthur E, Hainey T, Boyle JM. A systematic literature review of empirical evidence on computer games and serious games. Computers Education. 2012; 59(2):661-86. 
32. Sparapani VC, Borges ALV, Dantas IRO, Pan R, Nascimento LC. A criança com Diabetes Mellitus tipo 1 e seus amigos: a influência dessa interação no manejo da doença. Rev Latino-Am Enfermagem. 2012; 20(1):117-25.

33. Baranowski T, Buday R, Thompson DI, Baranowski
J. Playing for real: video games and stories for healthrelated behavior change. Am J Prev Med. 2008; 34:74-82.

34. Daley AJ. Can exergaming contribute to improving physical activity levels and health outcomes in children? Pediatrics. 2009; 124(2):763-77. 